\title{
Volume 3 - Número 2
}

\author{
REGINALDO PUJOL FILHO* \\ Pontifícia Universidade Católica do Rio Grande do Sul, Porto Alegre, RS, Brasil
}

— m tempos tão conturbados, manter uma revista dedicada à criação literária, —a pensar os processos criativos, a debater possibilidades para narrar e fazer literatura, será isso revolucionário?

Ou não?

O certo é que, revolucionária ou não, a Scriptorium chega a seu novo número, ele sim dedicado a revoluções, a grandes momentos de transformação, a livros, movimentos, ideias, que tiraram as coisas e as pessoas do seu lugar.

E temos como cúmplices em nosso dossiê dedicado às revoluções um combativo time de colaboradores e colaboradoras. Vinícius Carneiro vem pensar sobre Geroges Perec e o Oulipo em Restrições formais como revolução literária? Uma discussão sobre limites e deslimites das formas em literatura. Da França para Portugal, a escritora e doutoranda Paula Fábrio vem refletir sobre o exílio em seu Apontamentos sobre o exílio: ou a literatura como um reino; Já Thiane Nunes reflete nos traz a obra La Forêt Sacrilège de Jean-Pierre Duprey e encontros que ela possibilita em Um eclipse e três estrelas da manhã: Duprey, Toyen e Breton unidos em Sacrilégio; e fechando o dossiê, Roberto Bezerra de Menezes vem pensar uma obra indefinível e incontrolável como toda revolução em $A$ unidade deslizante da obra Photomaton \& Vox, de Herberto Helder.

Na área livre, diferentes autores, diferentes ideias em busca também de suas revoluções pessoais. Luiz Henrique De Nadal, em ensaio pessoal, nos apresenta seu projeto Isto não é um cachimbo - perfis literários para pensar sistema literário e a escrita de perfis em Perfis literários - notas sobre um projeto biográfico, crítico e ficcional; Paulo Maia abre o foco da revista e lê Sebastião Salgado no seu texto Olhar, memória, imaginário em Sebastião Salgado; já Marcelo Maldonado arrisca uma metodologia do processo criativo em suas notas Fragmentos de um discurso criativo: notas para uma metodologia de composição da história.

Este número ainda traz a resenha da obra Quando florirem salambás no tecto do Pico, de Conceição Lima, escrita por Naduska Mário Palmeira. E é claro, como não, é preciso revolucionar mas também manter alguma tradição: a criação literária na prática tem seu espaço aqui. Apresentamos o poema Just a note, de Beatriz de Campos Badim e o conto Éramos seis, de Talita Jabs Eger.

Desejando que estas leituras de algum modo desestruturem e baguncem o establishment das suas ideias, seguimos em frente. Avante!

\footnotetext{
* Escritor. Mestre em Escrita Criativa e doutorando em Escrita Criativa no Programa de Pós-graduação em Letras da Escola de Humanidades da Pontifícia Universidade Católica do Rio Grande do Sul (PUCRS). <reginaldo_pujol@yahoo.com.br>.
} 